\title{
Response of Eight Sweet Corn (Zea mays L.) Hybrids to Topramezone
}

\author{
Nader Soltani ${ }^{1}$, Peter H. Sikkema, John Zandstra, \\ John O'Sullivan, and Darren E. Robinson \\ University of Guelph Ridgetown Campus, Ridgetown, \\ Ontario, Canada NOP 2 CO
}

Additional index words. sweet corn, sensitivity, tolerance, BAS 670, herbicide injury

\begin{abstract}
Topramezone is a newly introduced herbicide for use in field corn (Zea mays L.) that may have potential for weed management in sweet corn. Tolerance of eight sweet corn hybrids to topramezone applied postemergence (POST) at $0,50,75,100,150$, and $300 \mathrm{~g}$ a.i. $\mathrm{ha}^{-1}$ were studied at one Ontario location in 2000 and two locations in 2001 and 2002. Topramezone applied POST at 50, 75, 100, and $150 \mathrm{~g} \cdot \mathrm{ha}^{-1}$ did not cause any visual injury in Calico Belle, CNS 710, Delmonte 2038, FTF 222, FTF 246, GH 2684, Reveille, and Rival sweet corn hybrids at 7 days after treatment (DAT) and caused minimal injury (less than 5\%) at $300 \mathrm{~g} \cdot \mathrm{ha}^{-1}$ in all hybrids. The initial sensitivity observed in these hybrids was minimal and transient with no effect on visual injury at 14 and 28 DAT. Topramezone applied POST did not reduce plant height, cob size, or marketable yield of the sweet corn hybrids included in this study. Based on these results, topramezone applied POST at the rates evaluated can be safely applied to Calico Belle, CNS 710, Delmonte 2038, FTF 222, FTF 246, GH 2684, Reveille, and Rival sweet corn.
\end{abstract}

Sweet corn (Zea mays L.) is an important field-grown vegetable crop in Ontario; nearly $170,000 \mathrm{t}$ of sweet corn are produced on 14,000 ha with a farm-gate value of $\$ 22.8$ million (Mailvaganam, 2006). Effective weed control is important for the production of sweet corn. The only herbicides registered for postemergence (POST) broadleaf weed control in sweet corn in Ontario are atrazine, bentazon, and bromoxynil (OMAFRA, 2006). More research is needed to identify POST herbicides that can effectively control emerged problem broadleaf and grass weeds in sweet corn production.

Topramezone is a newly introduced pyrazolone postemergence herbicide. Topramezone inhibits the activity of the 4-hydroxyphenyl pyruvate dioxygenase (HPPD) enzyme, which in susceptible weeds disrupts carotenoid synthesis, causing leaf bleaching, necrosis, and plant death (Anonymous, 2006). In field corn, topramezone can be applied in tank mixes with atrazine to control several broadleaf and grass weeds such as palmer amaranth (Amaranthus palmeri), common lambsquarters (Chenopdium album), velvetleaf (Abutilon theophrasti), kochia (Kochia scoparia), Amaranthus spp., Polygonum spp., Sinapis spp., Solanum spp., barnyardgrass (Echinochloa crus-galli), Digitaria

Received for publication 1 Aug. 2006. Accepted for publication 30 Aug. 2006.

Funding for this project was provided by the Ontario Processing Vegetable growers and various seed companies that provided seeds. We acknowledge T. Cowan and $\mathrm{K}$. McNaughton for their expertise and technical assistance in these studies. ${ }^{1}$ To whom reprint requests should be addressed; e-mail nsoltani@ridgetownc.uoguelph.ca. spp., Setaria spp., fall panicum (Panicum dichotomiflorum), proso-millet (Panicum miliaceum), and goosegrass (Eleucine indica), including ALS, glyphosate, and triazine-resistant biotypes (Anonymous, 2006).

The currently registered POST herbicides in sweet corn do not satisfactorily control late-emerging velvetleaf and triazine-resistant redroot pigweed (Amaranthus retroflexus). Atrazine suppresses velvetleaf and does not control the triazine-resistant biotypes, and bromoxynil provides only fair control of Amaranthus spp. Bentazon is weak on pigweed and ragweed (Ambrosia artemisiifolia) and can significantly injure some sweet corn hybrids (Diebold et al., 2004). Mesotrione can also injure some sweet corn hybrids (O'Sullivan et al., 2002) and does not control many annual grass weeds, including Setaria spp., fall panicum, and witchgrass (Panicum capillare). Topramezone controls many of these troublesome weeds (Anonymous, 2006; OMAFRA, 2006) and therefore would be of benefit to sweet corn growers in Ontario.

Sensitivity of sweet corn to herbicides is dependent on the application rate, hybrid, and environmental conditions. Some of the commonly grown sweet corn hybrids in Ontario such as Calico Belle, Delmonte 2038, and GH2684 have shown sensitivity to other herbicides such as AE F130360 (foramsulfuron), bentazon, CGA152005 (prosulfuron), mesotrione, nicosulfuron, primisulfuron, and RPA201772 (isoxaflutole) (Diebold et al., 2003, 2004; O'Sullivan and Sikkema 2001, 2002; O'Sullivan et al., 1999, 2000, 2002; Robinson et al., 1993). Hybrid sensitivity is an important factor for registration of herbicides in sweet corn. To our knowledge, there is no published information on the sensitivity of sweet corn hybrids to POST applications of topramezone. The objective of this study was to determine the tolerance of eight commonly grown processing sweet corn hybrids - Calico Belle, CNS 710, Delmonte 2038, FTF 222, FTF 246, GH 2684, Reveille, and Rival - to topramezone.

\section{Materials and Methods}

Field studies were conducted at the Huron Research Station, Exeter, Ontario, in 2001 and 2002 and the University of Guelph, Ridgetown Campus, Ridgetown, Ontario, in 2000 to 2002. The soil at Exeter was a Brookston clay loam with $23 \%$ sand, $47 \%$ silt, $30 \%$ clay, $4.0 \%$ organic matter, and $\mathrm{pH}$ of 7.7 in 2001 ; and $34 \%$ sand, $33 \%$ silt, $33 \%$ clay, $3.8 \%$ organic matter, and $\mathrm{pH}$ of 8.0 in 2002 . The soil at Ridgetown was a Watford/Brady loam with $50 \%$ sand, $29 \%$ silt, $21 \%$ clay, $8.2 \%$ organic matter, and $\mathrm{pH}$ of 6.8 in 2000 ; $51 \%$ sand, $32 \%$ silt, $17 \%$ clay, $5.5 \%$ organic matter, and pH of 7.2 in 2001 ; and $51 \%$ sand, $32 \%$ silt, $17 \%$ clay, $5.5 \%$ organic matter, and $\mathrm{pH}$ of 7.2 in 2002. Seedbed preparation at both locations consisted of fall moldboard plowing followed by two passes with a field cultivator in the spring.

The experiments were arranged in a splitplot design with four replications. The main plots were herbicide rates and subplots were eight sweet corn hybrids. Selection of herbicide rates was based on the manufacturer's recommended use rates at the time the study was initiated. Treatments consisted of a nontreated control and five rates of topramezone (a.i. of 50, 75, 100, 150, and $300 \mathrm{~g} \cdot \mathrm{ha}^{-1}$ ). Eight of the most commonly grown processing sweet corn hybrids in southwestern Ontario encompassing a range of endosperm genotypes were selected. Hybrids included: Calico Belle (se), CNS $710\left(s h_{2}\right)$, Delmonte $2038(s u)$, FTF $222(s u)$, FTF $246(s u)$, GH 2684 (se), Reveille (su), and Rival (su). The main plots were $6 \mathrm{~m}$ wide (eight rows) by 10 $\mathrm{m}$ long at Exeter and $6 \mathrm{~m}$ wide by $8 \mathrm{~m}$ long at Ridgetown. The row spacing was $75 \mathrm{~cm}$ and plants were thinned to a final plant population of 50,000 plants/ha. A preemergence application of a preformulated mixture of $S$ metolachlor plus atrazine (1:0.8) was applied immediately after planting with an a.i. of 2.16 $\mathrm{kg} \cdot \mathrm{ha}^{-1}$ in all trials, and plots were maintained weed-free by interrow cultivation and hand hoeing as required.

Topramezone was applied to 4 to 5 leaf stage sweet corn with a $\mathrm{CO}_{2}$-pressurized backpack sprayer calibrated to deliver 200 $\mathrm{L} \cdot \mathrm{ha}^{-1}$ with XR8002VS (Teejet XR8002VS Tip; Spraying Systems Co., Wheaton, Ill.) flat-fan nozzles at 241 and $207 \mathrm{kPa}$ pressure at Exeter and Ridgetown, respectively.

Visual crop injury was rated on a scale of $0 \%$ to $100 \%$ at 7,14 , and $28 \mathrm{~d}$ after treatment (DAT). A rating of $0 \%$ was defined as no visible effect of the herbicide and $100 \%$ was defined as plant death. Height of five randomly selected plants was determined 21 DAT by measuring from the soil surface to the highest point of the corn plant with the leaves fully extended. The entire row of 
sweet corn in each plot was harvested by hand at maturity and cob size, marketable (cobs greater than $5 \mathrm{~cm}$ in diameter) and total yield were determined. Because the statistical analyses for total and marketable yields were similar, only marketable yields are reported.

All data were subjected to analysis of variance. Tests were combined over locations and years and analyzed using the PROC MIXED procedure of SAS (SAS, 1999). Variances of percent injury at 7,14 , and 28 DAT, plant height, cob size, and yield were partitioned into the fixed effects of herbicide treatment, hybrids, and herbicide-by-hybrids interaction and into the random effects of test and block (test). Significance of random effects was tested using a Z-test of the variance estimate and fixed effects were tested using F-tests. Error assumptions of the variance analyses (random, homogeneous, normal distribution of error) were confirmed using residual plots and the Shapiro-Wilk normality test. To meet the assumptions of the variance analysis, visual injury at 7,14 , and 28 DAT and cob size data were subjected to an arsine square root transformation (Bartlett, 1947). Treatment means were separated using Fisher's protected least significant difference. Means of percent injury were compared on the transformed scale and were converted back to the original scale for presentation of results. Type I error was set at 0.05 for all statistical comparisons.

\section{Results and Discussion}

Visual injury. Visual injury symptoms included chlorosis and bleaching (whitening) of the leaves. Topramezone applied POST at $50,75,100$, and $150 \mathrm{~g} \cdot \mathrm{ha}^{-1}$ did not cause any visual injury in Calico Belle, CNS 710, Delmonte 2038, FTF 222, FTF 246, GH 2684, Reveille, and Rival sweet corn hybrids at 7 DAT but caused minimal injury (less than $5 \%$ ) at $300 \mathrm{~g} \cdot \mathrm{ha}^{-1}$ in all hybrids (Table 1). There was no visual injury in any hybridtopramezone rate combinations at 14 and 28 DAT (data not shown). Visual injury generally did not increase as topramezone rate increased, which is in contrast with previous research on many of the same sweet corn hybrids (O'Sullivan et al., 2001, 2002). One HPPD inhibitor, RPA 201,772 (isoxaflutole), injured Calico Belle $10 \%$ to $100 \%$ and caused 10 and $73 \%$ visual injury in Rival, Delmonte 2038, GH 2690, CNS 710, and Reveille (O'Sullivan et al., 2001). O'Sullivan et al. (2002) observed that mesotrione, also an HPPD inhibitor, significantly injured Delmonte 2038 and Calico Belle, caused slight injury to Rival, and did not injure CNS 710 . In the present study, all hybrids showed no or minimal (less than 5\%) injury at all topramezone rates evaluated.

Plant height. Sweet corn height data are reported for each hybrid and rate individually, and heights were compared among rates and hybrids (Table 2). The visual injury observed in this study was reflected in the plant height. Topramezone applied POST at all rates did not reduce sweet corn hybrid

Table 1. Sweet corn hybrid visual injury (\%) $7 \mathrm{~d}$ after treatment with topramezone applied postemergence at Exeter, ON, Canada, in 2001 to 2002 and Ridgetown, ON, Canada, in 2000 to $2002 .{ }^{z}$

\begin{tabular}{lcccccc}
\hline & \multicolumn{5}{c}{ Topramezone rate (a.i. g.ha $\left.{ }^{-1}\right)$} \\
\cline { 2 - 7 } Sweet corn hybrid & 50 & 75 & 100 & 150 & 300 & Standard error \\
\hline \cline { 2 - 6 } Calico Belle & $0 \mathrm{bX}$ & $0 \mathrm{bX}$ & $0 \mathrm{bX}$ & $0 \mathrm{bX}$ & $2 \mathrm{aX}$ & 1 \\
CNS 710 & $0 \mathrm{bX}$ & $0 \mathrm{bX}$ & $0 \mathrm{bX}$ & $0 \mathrm{bX}$ & $2 \mathrm{aX}$ & 1 \\
Delmonte 2038 & $0 \mathrm{bX}$ & $0 \mathrm{bX}$ & $0 \mathrm{bX}$ & $0 \mathrm{bX}$ & $4 \mathrm{aX}$ & 2 \\
FTF 222 & $0 \mathrm{bX}$ & $0 \mathrm{bX}$ & $0 \mathrm{bX}$ & $0 \mathrm{bX}$ & $2 \mathrm{aX}$ & 1 \\
FTF 246 & $0 \mathrm{bX}$ & $0 \mathrm{bX}$ & $0 \mathrm{bX}$ & $0 \mathrm{bX}$ & $2 \mathrm{aX}$ & 1 \\
GH 2684 & $0 \mathrm{bX}$ & $0 \mathrm{bX}$ & $0 \mathrm{bX}$ & $0 \mathrm{bX}$ & $2 \mathrm{aX}$ & 1 \\
Reveille & $0 \mathrm{bX}$ & $0 \mathrm{bX}$ & $0 \mathrm{bX}$ & $0 \mathrm{bX}$ & $2 \mathrm{aX}$ & 1 \\
Rival & $0 \mathrm{bX}$ & $0 \mathrm{bX}$ & $0 \mathrm{bX}$ & $0 \mathrm{bX}$ & $2 \mathrm{aX}$ & 1 \\
Standard error & 0 & 0 & 0 & 0 & 2 & \\
\hline
\end{tabular}

${ }^{2}$ Results are averaged for both locations and years; means followed by the same letter within a row (a-b) or column (X-Z) are not significantly different according to Fisher's protected least significant difference test $(P<0.05)$ on the arsine (square root) transformed scale; means presented are backtransformed from the arsine (square root) scale.

Table 2. Sweet corn hybrid height $(\mathrm{cm}) 28 \mathrm{~d}$ after treatment with topramezone applied postemergence at Exeter, ON, Canada, in 2001 to 2002 and Ridgetown, ON, Canada, in 2000 to 2002. ${ }^{z}$

\begin{tabular}{llcccccc}
\hline & \multicolumn{7}{c}{ Topramezone rate (a.i. g.ha $\left.{ }^{-1}\right)$} \\
\cline { 2 - 8 } Sweet corn hybrid & 0 & 50 & 75 & 100 & 150 & 300 & Standard error \\
\cline { 2 - 8 } Calico Belle & $108 \mathrm{aYZ}$ & $108 \mathrm{aYZ}$ & $109 \mathrm{aYZ}$ & $108 \mathrm{aYZ}$ & $107 \mathrm{aYZ}$ & $109 \mathrm{aYZ}$ & 6 \\
CNS 710 & $103 \mathrm{aZ}$ & $102 \mathrm{aZ}$ & $103 \mathrm{aZ}$ & $103 \mathrm{aZ}$ & $103 \mathrm{aZ}$ & $103 \mathrm{aZ}$ & 8 \\
Delmonte 2038 & $115 \mathrm{aX}$ & $116 \mathrm{aX}$ & $115 \mathrm{aX}$ & $116 \mathrm{aX}$ & $115 \mathrm{aX}$ & $115 \mathrm{aX}$ & 6 \\
FTF 222 & $112 \mathrm{aXY}$ & $113 \mathrm{aXY}$ & $111 \mathrm{aXY}$ & $113 \mathrm{aXY}$ & $112 \mathrm{aXY}$ & $115 \mathrm{aX}$ & 6 \\
FTF 246 & $114 \mathrm{aX}$ & $114 \mathrm{aXY}$ & $113 \mathrm{aXY}$ & $114 \mathrm{aXY}$ & $114 \mathrm{aXY}$ & $113 \mathrm{aXY}$ & 5 \\
GH 2684 & $111 \mathrm{aXY}$ & $111 \mathrm{aXY}$ & $112 \mathrm{aXY}$ & $112 \mathrm{aXY}$ & $112 \mathrm{aXY}$ & $111 \mathrm{aXY}$ & 5 \\
Reveille & $105 \mathrm{aZ}$ & $108 \mathrm{aYZ}$ & $109 \mathrm{aYZ}$ & $109 \mathrm{aYZ}$ & $108 \mathrm{aYZ}$ & $110 \mathrm{aXYZ}$ & 5 \\
Rival & $108 \mathrm{aYZ}$ & $109 \mathrm{aYZ}$ & $110 \mathrm{aYZ}$ & $108 \mathrm{aYZ}$ & $108 \mathrm{aYZ}$ & $109 \mathrm{aYZ}$ & 6 \\
Standard error & 5 & 6 & 5 & 5 & 5 & 5 & \\
\hline
\end{tabular}

${ }^{2}$ Results are averaged for both locations and years; means followed by the same letter within a row (a-b) or column (X-Z) are not significantly different according to a Fisher's protected least significant difference test $(P<0.05)$ on the arsine (square root) transformed scale; means presented are backtransformed from the arsine (square root) scale.

heights (Table 2). Plant height was unaffected by increasing topramezone rate. Studies with other herbicides have shown rate and hybrid can affect plant height in sweet corn. O'Sullivan et al. (2002) found a reduction in plant height that was dependent on mesotrione rate in Delmonte 2038; however, mesotrione did not adversely affect Calico Belle, CNS 710, or Rival height. Thifensulfuron applied POST at $12 \mathrm{~g} \cdot \mathrm{ha}^{-1}$ reduced sweet corn height by $76 \mathrm{~cm}$ in Delmonte 2038 and $26 \mathrm{~cm}$ in GH2684; and heights were generally reduced as the herbicide rate increased (Soltani et al., 2005). Robinson et al., (1994) reported POST nicosulfuron applications significantly reduced Zenith sweet corn height. Grey et al. (2000) reported height reduction in four of 10 sweet corn hybrids treated with nicosulfuron. O'Sullivan et al. (2000) observed reduced plant height with increased nicosulfuron rates in 11 hybrids evaluated. In two other experiments, plant height was reduced in five and three of eight hybrids evaluated (O'Sullivan et al., 2000).

Cob size. Sweet corn cob size data are reported for each hybrid and rate individually, and cob size was compared among topramezone rates and sweet corn hybrids (Table 3). Responses were similar to visual injury and height. Topramezone applied POST at 50, 75, 100,150 , and $300 \mathrm{~g} \cdot \mathrm{ha}^{-1}$ did not cause any reduction in cob size in Calico Belle, CNS 710, Delmonte 2038, FTF 222, FTF 246, GH 2684, Reveille, or Rival sweet corn hybrids
(Table 3). Other studies have shown that herbicides such as thifensulfuron applied POST can reduce cob size $9 \%$ to $67 \%$ in some sweet corn hybrids such as Delmonte 2038 and GH 2684 (Soltani et al., 2005).

Yield. Sweet corn yield data are reported for each hybrid and rate individually, and yields were compared among topramezone rates and hybrids (Table 4). Topramezone applied POST at 50, 75, 100, 150, and 300 $\mathrm{g} \cdot \mathrm{ha}^{-1}$ did not reduce Calico Belle, CNS 710, Delmonte 2038, FTF 222, FTF 246, GH 2684, Reveille, or Rival sweet corn hybrid yields (Table 4). Again, these results are in contrast to other studies that have shown Delmonte 2038 is one of the most sensitive hybrids in Ontario exhibiting as much as $94 \%$ yield reduction when treated with some herbicides, including some HPPD enzyme inhibitors such as mesotrione or RPA 201,772 (isoxaflutole) (O'Sullivan et al., 2001,2002 ). Yield was unaffected as topramezone rate was increased from 50 to 300 $\mathrm{g} \cdot \mathrm{ha}^{-1}$, which is in contrast with Grey et al. (2000) and O'Sullivan and Sikkema (2001) who found differential hybrid yield reduction and rate responses with other herbicides in sweet corn. Thifensulfuron applied POST reduced yield $21 \%$ to $98 \%$ in Delmonte 2038 and GH 2684 sweet corn hybrids (Soltani et al., 2005). O'Sullivan et al. (2000) observed significant variability in yield loss among a range of sweet corn hybrids treated with nicosulfuron. Grey et al. 
Table 3. Sweet corn hybrid cob size (g) treated with topramezone applied postemergence at Exeter, ON, Canada, in 2001 to 2002 and Ridgetown, ON, Canada, in 2000 to $2002 .{ }^{2}$

\begin{tabular}{lccccccc}
\hline & \multicolumn{7}{c}{ Topramezone rate (a.i. g.ha- $\left.{ }^{-1}\right)$} \\
\cline { 2 - 8 } Sweet corn hybrid & 0 & 50 & 75 & 100 & 150 & 300 & Standard error \\
\cline { 2 - 8 } Calico Belle & $310 \mathrm{aY}$ & $310 \mathrm{aY}$ & $315 \mathrm{aY}$ & $317 \mathrm{aY}$ & $316 \mathrm{aY}$ & $318 \mathrm{aY}$ & 13 \\
CNS 710 & $288 \mathrm{aZ}$ & $288 \mathrm{aZ}$ & $286 \mathrm{aZ}$ & $279 \mathrm{aZ}$ & $286 \mathrm{aZ}$ & $282 \mathrm{aZ}$ & 13 \\
Delmonte 2038 & $344 \mathrm{aX}$ & $343 \mathrm{aX}$ & $330 \mathrm{aX}$ & $325 \mathrm{aX}$ & $356 \mathrm{aX}$ & $343 \mathrm{aX}$ & 15 \\
FTF 222 & $311 \mathrm{aY}$ & $314 \mathrm{aY}$ & $310 \mathrm{aY}$ & $310 \mathrm{aY}$ & $315 \mathrm{aY}$ & $306 \mathrm{aY}$ & 14 \\
FTF 246 & $298 \mathrm{aYZ}$ & $291 \mathrm{aYZ}$ & $305 \mathrm{aYZ}$ & $300 \mathrm{aYZ}$ & $302 \mathrm{aYZ}$ & $299 \mathrm{aYZ}$ & 13 \\
GH 2684 & $313 \mathrm{aY}$ & $316 \mathrm{aY}$ & $315 \mathrm{aY}$ & $310 \mathrm{aY}$ & $318 \mathrm{aY}$ & $311 \mathrm{aY}$ & 12 \\
Reveille & $299 \mathrm{aYZ}$ & $295 \mathrm{aYZ}$ & $299 \mathrm{aYZ}$ & $294 \mathrm{aYZ}$ & $294 \mathrm{aYZ}$ & $301 \mathrm{aYZ}$ & 11 \\
Rival & $293 \mathrm{aYZ}$ & $304 \mathrm{aYZ}$ & $292 \mathrm{aYZ}$ & $304 \mathrm{aYZ}$ & $293 \mathrm{aYZ}$ & $304 \mathrm{aYZ}$ & 11 \\
Standard error & 9 & 9 & 10 & 9 & 10 & 10 & \\
\hline
\end{tabular}

${ }^{2}$ Results are averaged for both locations and years; means followed by the same letter within a row (a-b) or column (X-Z) are not significantly different according to a Fisher's protected least significant difference test $(P<0.05)$ on the arsine (square root) transformed scale; means presented are backtransformed from the arsine (square root) scale.

Table 4. Sweet corn hybrid marketable yield $\left(\mathrm{t} \cdot \mathrm{ha}^{-1}\right)$ treated with various rates of topramezone applied postemergence at Exeter, ON, Canada, in 2001 to 2002 and Ridgetown, ON, Canada, in 2000 to $2002 .{ }^{2}$

\begin{tabular}{llllllll}
\hline & \multicolumn{7}{c}{ Topramezone rate (a.i. g.ha $\left.{ }^{-1}\right)$} \\
\cline { 2 - 8 } Sweet corn hybrid & 0 & 50 & 75 & 100 & 150 & 300 & Standard error \\
\cline { 2 - 8 } Calico Belle & $12.5 \mathrm{aYZ}$ & $13.0 \mathrm{aYZ}$ & $12.0 \mathrm{aYZ}$ & $12.8 \mathrm{aYZ}$ & $13.1 \mathrm{aYZ}$ & $13.4 \mathrm{aYZ}$ & 1.4 \\
CNS 710 & $10.2 \mathrm{aZ}$ & $9.2 \mathrm{aZ}$ & $9.8 \mathrm{aZ}$ & $9.4 \mathrm{aZ}$ & $10.4 \mathrm{aZ}$ & $10.6 \mathrm{aZ}$ & 1.4 \\
Delmonte 2038 & $16.5 \mathrm{aX}$ & $17.4 \mathrm{aX}$ & $17.0 \mathrm{aX}$ & $17.4 \mathrm{aX}$ & $17.6 \mathrm{aX}$ & $17.1 \mathrm{aX}$ & 1.4 \\
FTF 222 & $13.6 \mathrm{aXY}$ & $12.6 \mathrm{aXY}$ & $13.3 \mathrm{aXY}$ & $12.7 \mathrm{aXY}$ & $14.1 \mathrm{aXY}$ & $13.4 \mathrm{aYZ}$ & 1.5 \\
FTF 246 & $11.2 \mathrm{aYZ}$ & $11.5 \mathrm{aYZ}$ & $11.5 \mathrm{aYZ}$ & $11.6 \mathrm{aYZ}$ & $12.3 \mathrm{aYZ}$ & $12.1 \mathrm{aYZ}$ & 1.5 \\
GH 2684 & $14.4 \mathrm{aXY}$ & $14.6 \mathrm{aXY}$ & $15.1 \mathrm{aXY}$ & $14.5 \mathrm{aXY}$ & $15.0 \mathrm{aXY}$ & $14.2 \mathrm{aXY}$ & 1.5 \\
Reveille & $12.4 \mathrm{aYZ}$ & $12.0 \mathrm{aYZ}$ & $12.5 \mathrm{aYZ}$ & $12.3 \mathrm{aYZ}$ & $13.0 \mathrm{aYZ}$ & $12.6 \mathrm{aYZ}$ & 1.5 \\
Rival & $11.5 \mathrm{aYZ}$ & $11.6 \mathrm{aYZ}$ & $12.0 \mathrm{aYZ}$ & $12.7 \mathrm{aYZ}$ & $12.8 \mathrm{aYZ}$ & $11.6 \mathrm{aYZ}$ & 1.4 \\
Standard error & 1.3 & 1.4 & 1.4 & 1.5 & 1.5 & 1.6 & \\
\hline
\end{tabular}

${ }^{2}$ Results are averaged for both locations and years; means followed by the same letter within a row (a-b) or column (X-Z) are not significantly different according to a Fisher's protected least significant difference test $(P<0.05)$ on the arsine (square root) transformed scale; means presented are backtransformed from the arsine (square root) scale.

(2000) found that only one of 11 sweet corn hybrids had a decreased yield with nicosulfuron. Robinson et al. (1994) observed that POST applications of nicosulfuron resulted in complete crop loss in one hybrid (Merit), a $50 \%$ reduction in yield in another, but no reduction in yield in Zenith. Stall and Bewick (1992) determined that four of 12 hybrids demonstrated a response to nicosulfuron rate and marketable yield was significantly lower at higher rates. Similar sweet corn yield responses were also reported with other herbicides such as AE F130360 (foramsulfuron), CGA 152,005 (prosulfuron), primisulfuron, and rimsulfuron (Diebold et al., 2003; O'Sullivan et al., 1998; O'Sullivan and Sikkema 2001, 2002; Van Wychen et al., 1997).

\section{Conclusions}

Differential sensitivity of sweet corn hybrids to other herbicides, including some HPPD enzyme inhibitors, has been reported in other studies conducted in Ontario (Die- bold et al., 2003, 2004; O'Sullivan and Sikkema 2001, 2002; O'Sullivan et al., 1999, 2000, 2002; Soltani et al., 2005). In this study, differential sensitivity to topramezone POST was not observed in Calico Belle, CNS 710, Delmonte 2038, FTF 222, FTF 246, GH 2684, Reveille, or Rival sweet corn hybrids. Minimal visual injury seen in sweet corn hybrids at early growth stages was transient and did result in any reduction in plant height, cob size and yield. There was generally no difference in crop injury as the rate of topramezone was increased. Topramezone applied POST from 50 to $300 \mathrm{~g} \cdot \mathrm{ha}^{-1}$ can be safely applied to Calico Belle, CNS 710, Delmonte 2038, FTF 222, FTF 246, GH 2684, Reveille, and Rival sweet corn hybrids.

\section{Literature Cited}

Anonymous. 2006. Impact Herbicide, technical information and use guide for field corn, sweet corn and popcorn. AMVAC, Los Angeles, Calif.

Bartlett, M.S. 1947. The use of transformations. Biometrics 3:39-52.
Diebold, S., D. Robinson, J. Zandstra, J. O'Sullivan, and P. Sikkema. 2003. Sweet corn (Zea mays) cultivar sensitivity to AE F130360. Weed Technol. 17:127-132.

Diebold, S., D. Robinson, J. Zandstra, J. O'Sullivan, and P. Sikkema. 2004. Sweet corn (Zea mays) cultivar sensitivity to bentazon. Weed Technol. 18:982-987.

Grey, T.L., D.C. Bridges, P. Raymer, D. Day, and D. Scott NeSmith. 2000. Differential tolerance of fresh market sweet corn cultivars to the herbicides nicosulfuron and primisulfuron. HortScience 35:1070-1073.

Mailvaganam, S. 2006. Area, production and farm value of specified commercial vegetable crops, Ontario, 2005www.omafra.gov.on.ca/english/ stats/hort/vegsummetric 05 .html13 July 2006.

Ontario Ministry of Agriculture, Food, and Rural Affairs [OMAFRA]. 2006. Guide to weed control. Publication 75. Toronto, ON, Ontario Ministry of Agriculture, Food, and Rural Affairs.

O'Sullivan, J. and P. Sikkema. 2001. Sweet corn (Zea mays) cultivar sensitivity to CGA 152005 postemergence. Weed Technol. 15:204-207.

O'Sullivan, J. and P. Sikkema. 2002. Sweet corn (Zea mays) cultivar tolerance to primisulfuron. Can. J. Plant Sci. 82:261-264.

O'Sullivan, J., P. Sikkema, and R.J. Thomas. 2000. Sweet corn (Zea mays) cultivar tolerance to nicosulfuron. Can. J. Plant Sci. 80:419-423.

O'Sullivan, J., R.J. Thomas, and W.J. Bouw. 1998. Tolerance of sweet corn (Zea mays) cultivars to rimsulfuron. Weed Technol. 12:258-261.

O'Sullivan, J., R.J. Thomas, and W.J. Bouw. 1999. Effect of flumetsulam plus clopyralid soil residues on several vegetable crops and on sweet corn (Zea mays) cultivars grown in rotation. Weed Technol. 13:303-307.

O'Sullivan, J., R.J. Thomas, and P. Sikkema. 2001. Sweet corn (Zea mays) cultivar sensitivity to RPA 2017721. Weed Technol. 15:332 336.

O’Sullivan, J., J. Zandstra, and P. Sikkema. 2002. Sweet corn (Zea mays) cultivar sensitivity to mesotrione. Weed Technol. 16:421-425.

Robinson, D.K., D.W. Monks, and J.R. Schultheis. 1994. Effect of nicosulfuron applied postemergence and post-directed on sweet corn (Zea mays) tolerance. Weed Technol. 8:630-634.

Robinson, D.K., D.W. Monks, J.R. Schultheis, and A.D. Worsham. 1993. Sweet corn (Zea mays) cultivar tolerance to application timing of nicosulfuron. Weed Technol. 7:840-843.

Stall, W.M. and T.A. Bewick. 1992. Sweet corn cultivars respond differentially to the herbicide nicosulfuron. HortScience 27:131-133.

Statistical Analysis Systems [SAS]. 1999. The SAS System for Windows, Release 8.0. Cary, N.C. Statistical Analysis Systems Institute.

Soltani, N., P.H. Sikkema, and D.E. Robinson. 2005. Sweet corn (Zea mays) hybrids responses to thifensulfuron-methyl. HortScience 40:1381-1383.

Van Wychen, L.R., R.G. Harvey, T.M. Anthon, and J.L. Kutil. 1997. Sweet corn hybrid tolerance to ALS-herbicides study. North Cent. Weed Sci. Soc. Res. Rep. 54:7-9. 